\title{
Ultra-magnesian komatiites of phanerozoic age, from SE Spain
}

Nixon, P.H. ${ }^{1}$, and Pearson, D.G. ${ }^{2}$

1. School of Earth Sciences, University of Leeds, Leeds LS2 9JT, United Kingdom

2. Department of Geological Sciences, University of Durham, Durham DH1 3LE

Spinifex-textured "harzburgites" were first described from the Betic Cordilleras in SE Spain, near Cerro del Almirez, $10 \mathrm{~km}$ north of Laujar de Andarax, Almeria Province, by Jansen (1936) and recently by Burgos et al. (1980), Morten and Puga (1984) and in unpublished reports by Harte (1988) and Beaven (1988) - Fig 1. The abundant spinifex-textured rocks are associated with harzburgites without spinifex texture and serpentinite in outcrops extending over $2 \mathrm{~km}$. Beaven (1988) describes a similar, but smaller occurrence $20 \mathrm{~km}$ to the west at Montenegro. The spinifex textured rocks can be classified as komatiites by reason of their volcanic origin indicated by rapidly crystallised spinifex textured olivines. The present composition of these rocks contains about $10 \%$ more $\mathrm{MgO}$ than their Archaean counterparts (Table 1) and could be referred to as ultra-high magnesian komatiites, uMgk.

\section{Field and structural relationships}

The $\mathrm{uMgk}$ are associated with eclogitic metabasalts with relict pillow and amygdaloidal structures and the whole suite has been grouped as metaophiolites (Puga et al. ,1989). They occur within the NevadoFilabride complex which consists mainly of medium grade regionally metamorphosed garnet metapelites. This interpretation constrains their age using alpine metamorphic events to between Trias and Cretaceous, i.e., extremely young for ultramafic komatiites virtually all of which are Archaean. However, we believe that they are of even younger age since the rocks are in fault contact with the Nevado-Filabride garnet schists and lack a metamorphic overprint compatible with that shown by the eclogitic rocks (Hart, 1988). Contact metamorphosed calcareous and ferruginous proto-Mediterranean sea floor sediments represented by assemblages of tremolite, humite, diopside, dolomite, specularite and chlinochlore resulted from in/extrusion of $\mathbf{u M g k}$. These locally hornfelsed sediments form part of overlying discontinuous outcrops of the low grade regionally metamorphosed higher Betic nappes (Fig 1). This observation is consistent with the timing of komatiite emplacement being more recent (post main alpine metamorphism) than suggested above, and possibly coeval with the ultramafic complexes of Ronda and Beni Bousera (Fig.1).

\section{Geochemical considerations and comparison with Archaean komatiites.}

$\mathrm{MgO}$ contents of the Spanish rocks are the highest recorded for spinifex textured rocks (Morten and Puga, 1984). Archaean spinifex-textured non-cumulate komatiites rarely exceed $32 \% \mathrm{MgO}$ on an anhydrous basis (Arndt and Nisbet, 1982). It seems possible that secondary alteration may have drastically increased their $\mathrm{MgO}$ content, but the striking spinifex texture of these rocks leave little doubt that they were originally high MgO liquids of some sort. However, the fairly low LOI's and Ti contents (Table 1) may argue against major chemical change by alteration. The Spanish uMgk are characterised by high $\mathrm{Mg} / \mathrm{Fe}$ ratios which are a reflection of the abundance of magnesian spinifex olivines $\left(\mathrm{Fo}_{89-90}\right)$ and granular orthopyroxenes $\left(\mathrm{En}_{90}\right)$. The $\mathrm{NiO}$ contents are high, usually ascribed to the forsterite control on fractionation, but $\mathrm{Cr}_{2} \mathrm{O}_{3}$ contents are similar to Archaean komatiites. Levels of $\mathrm{Al}, \mathrm{Ti}$ and $\mathrm{CaO}$ are greatly below the Archaean komatiite 'norms' resulting in low $\mathrm{CaO} / \mathrm{Al}_{2} \mathrm{O}_{3}$ ratios. These ultra depleted characteristics of $\mathbf{u M g k}$ are apparent in the low total REE contents which are mostly below chondrite and much lower than in Archaean komatiites (cf. 1 - 5x chondrite in Western Australian examples; Claoué-Long et al., 1984). REE patterns are somewhat saucer-shaped with marked HREE enrichment (Fig. 2) and perhaps more compatible with peridotitic residues that have been slightly re-enriched, or cumulates were it not for their demonstrably crystallised textures. The textures do not appear to mimic the bladed olivine textures of secondary, metamorphic origin sometimes described in altered ultramafic rocks (e.g. Collerson et al, 1976) although there are strong compositional similarities with these rocks. 


\section{Regional tectonics, komatiite petrogenesis and emplacement}

The notion of the uMgk requiring very high mantle potential temperatures beneath this region, such as in a large plume, in Tertiary times, is not compatible with the know tectonic history of the area. The generation of uMgk could be related to localised high mantle thermal gradients resulting from unusual tectonic conditions. During convergence of the African and European plates in the Paleogene an E-W collisional ridge with thickened roots developed in the position of the Alboran Sea (Fig. 1, and Platt and Visser, 1989; Doblas and Oyarzun, 1989). Convective removal of the lithospheric root at $19 \mathrm{Ma}$ (upper Oligocene), may have allowed localised upwelling of peridotite diapirs, represented by Ronda and Beni Bousera, both with high PT mineralogy (pyrope and graphitised diamond; Davies et al, (1993 ) and Pearson et al. (1989). The graphitised nature of the diamond in these massifs suggests hotter than usual conditions during upwelling. Archaean mantle temperatures required to generate komatiites in Belingwe, Zimbabwe, and Barbarton, Swaziland have been estimated at 1800C and 1900C respectively (Bickle, 1993). If the MgO contents of the Spanish uMgk are primary they would require even higher temperatures which seems unlikely given their recent age. However, given that the uMgk are closely associated with serpentinites it seems possible that the melts were hydrous and hence could have been generated at temperatures lower by some $250^{\circ} \mathrm{C}$ (Parman et al., 1997). A hydrous melt may have also promoted growth of the spinifex texture. Another problem is how the uMgk became so highly depleted. Morten and Puga (1984) have suggested that they were harzburgites intruded as a "mush" but recognised that textural evidence is against this, except possibly for the lesser abundant granular harzburgites. We have not ruled out the possibility that the uMgk melt was generated at depths at which majorite crystallised and sank, but below the depth of olivine density cross over (Ohtani et al., 1995) which floated and enriched the magma. The extent to which the observed compositions and textures are primary is still being constrained.

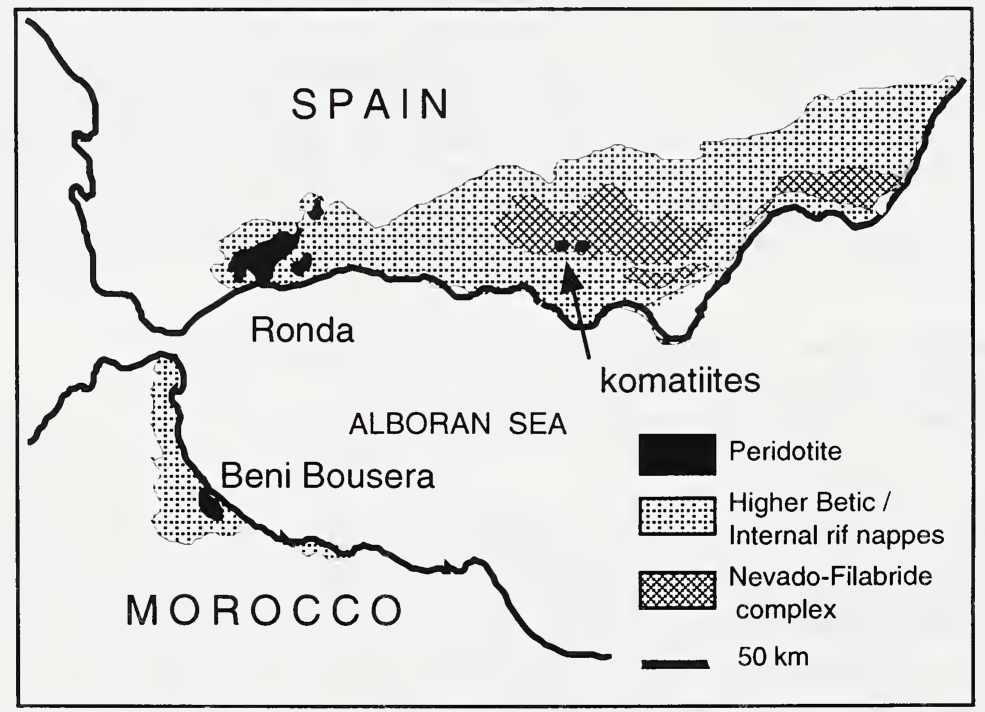

Fig.1 : Simplified map of the western Mediterranean area showing the location of the ultra magnesian komatiites of Cerro del Almirez and Montenegro, Almeria Province.

\begin{tabular}{crrrr}
$\mathrm{PHN}$ & 5873 & 5877 & 5893 & \multicolumn{1}{c}{ No 1} \\
\hline $\mathrm{TiO} 2$ & 0.06 & 0.06 & 0.06 & 0.06 \\
$\mathrm{Al}_{2} \mathrm{O}_{3}$ & 2.10 & 1.41 & 2.31 & 2.43 \\
$\mathrm{MgO}$ & 41.57 & 36.15 & 41.85 & 40.93 \\
$\mathrm{CaO}$ & 0.04 & 0.41 & 0.04 & 0.16 \\
I.o.i. & 3.75 & 11.53 & 4.34 & 6.54
\end{tabular}

Table 1: PHN 5873, 5877. Spinifex-textured komatiites,Cerro del Almirez, and Montenegro. PHN 5893. Non spinifex ultramafic, Cerro del Almirez. Analyses by XRF, Alan Grey. No 1. Ave. of 6 spinifex-like textured harzburgites, Cerro del Almirez. (Morten and Puga, 1984) 


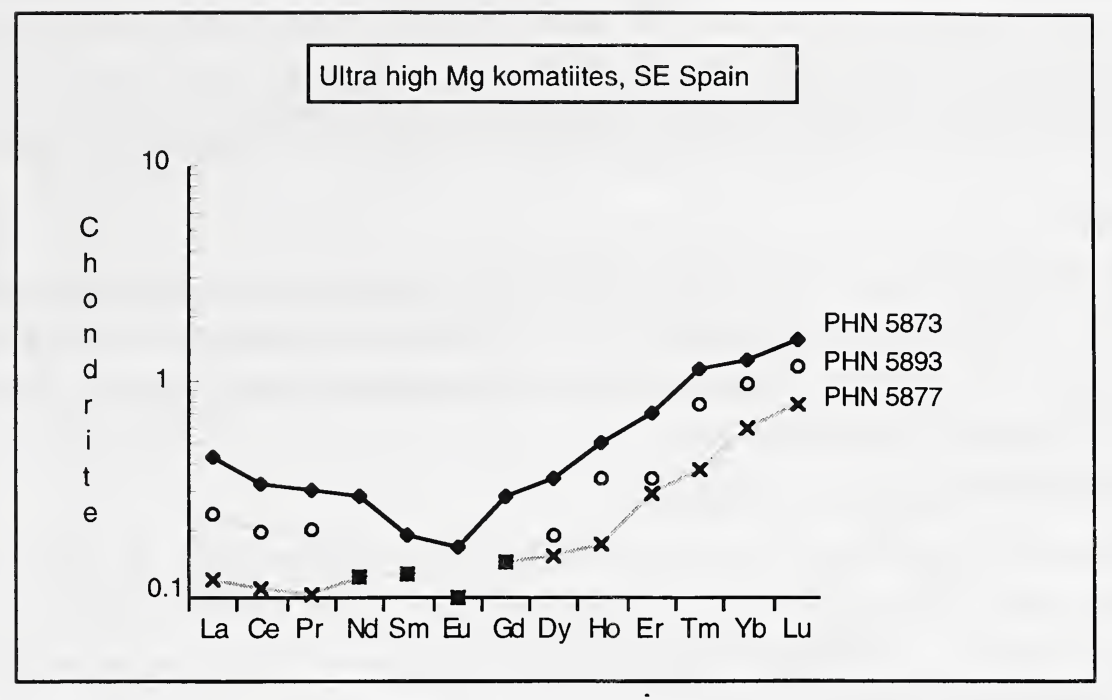

Fig. 2 : REE analyses by G. Nowell by ICP,MS.

\section{References}

Arndt, N.T. and Nisbet, E.G., 1982, Komatiites, London, George Allen and Unwin, 526pp.

Beaven, D.C., 1988, Landsat imagery and regional geology of the Betic Cordillera. Laujar, Almeria

Bickle. M., 1993, Plume origin for komatiites. Nature, 365, 390-391.

Province, SE Spain. Unpubl. rep. Dept. Earth Sci., Univ. Leeds.

Burgos, J., Diaz de Frederico, A., Morten, L., and Puga, E., 1980, The ultramafic rocks from the Cerro del Almirez, Sierra Nevada Complex, Betic Cordillera, Spain: prelim. report. Cuad. Geol., p. 157-165.

Claoué-Long, J. C., Thirlwall, M. F., and Nesbitt, R. W., 1984, Revised Sm-Nd systematics of Kambalda greenstones, Western Australia. Nature, 307, 697-701.

Collerson. K.D., Jesseau, C.W., and Bridgwater, D., 1976, Contrasting types of bladed olivine in ultramafic rocks from the Archean of Labrador: Can. J. Earth. Sci. 13, p. 442-450.

Davies, G., Nixon, P. H., Pearson, D. R. and Obata, M., 1993, Tectonic implications of graphitised diamonds from the Ronda peridotite massif, southern Spain. Geology, 21, p. 471-474.

Doblas, M., and Oyarzun, R., 1989, "Mantle core complexes" and Neogene extensional detachment tectonics in the western Betic Cordilleras, Spain: an alternative model for the emplacement of the Ronda peridotite. Earth Planet. Sci. Lett. 93, p. 7684.

Harte, A., 1988, The Cerro del Almirez ultramafic complex. Unpub. rep. Dept. Earth Sci., Univ. Leeds.

Jansen. H., 1936, De Geologie van de Sierra de Baza en van de aangrenzende gebieden der Sierra Nevada de los Filibrides (zuid-`spanje). These. Univ. Amsterdam 99pp.

Morten, L. and Puga, E., 1984, Blades of olivines and opx in ultramafic rocks from Cerro del Almirez, Sierra Nevada Complex, Spain: relics of quench-textured harzburgites? N. Jb. Mh., 5, p. 211-218.

Ohtani, E., Nagata, Y., Suzuki, A., and Kato, T., 1995, Melting relationships of peridotite and the density crossover in planetary mantles. Chemical Geol., 120, 207-221.

Parman, S. W., Dann, J. C., Grove, T. L., and de Wit, M. J., 1997, Emplacement conditions of komatiite magmas from the 3.49 Ga Komati Formation, S. Africa. Eart Planet. Sci. Lett., 150, 303-323.

Pearson, D. G., Davies, G., Nixon, P. H., and Milledge, H.J. 1989, Graphite diamonds from a peridotite massif in Morocco and implications for anomalous diamond occurrences. Nature, 338, p. 60-62.

Platt, J. P., and Vissers, R. L. M., 1989, Extensional collapse of thickened continental lithosphere: a working hypothesis for the Alboran Sea and Gibraltar arc. Geology, 17, p. 540-543.

Puga, E., Diaz de Frederico, A., Bargossi, G. M., and Morten, L., 1989, The Nevado-Filabride metaophiolitic association in the Cobdar region (Betic Cordillera, SE Spain): Geodyn Acta, 3, p. 17-36. 